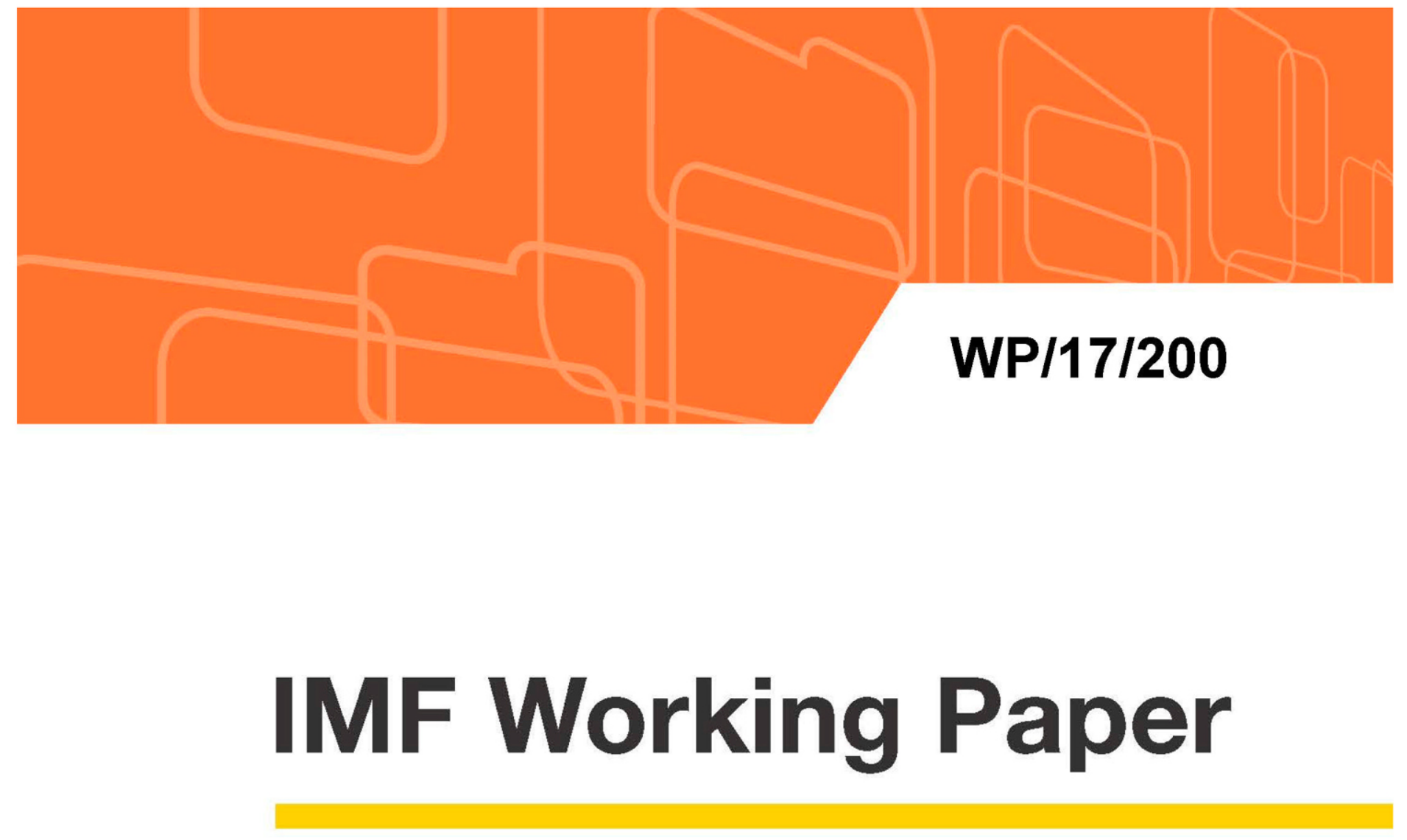

\title{
The Effect of Leverage on Asset Sales Between Financial Institutions
}

\author{
by Sonali Das
}

IMF Working Papers describe research in progress by the author(s) and are published to elicit comments and to encourage debate. The views expressed in IMF Working Papers are those of the author(s) and do not necessarily represent the views of the IMF, its Executive Board, or IMF management.

$$
\text { I N T E R N A T I O N A L M O N E T A R Y F U N D }
$$




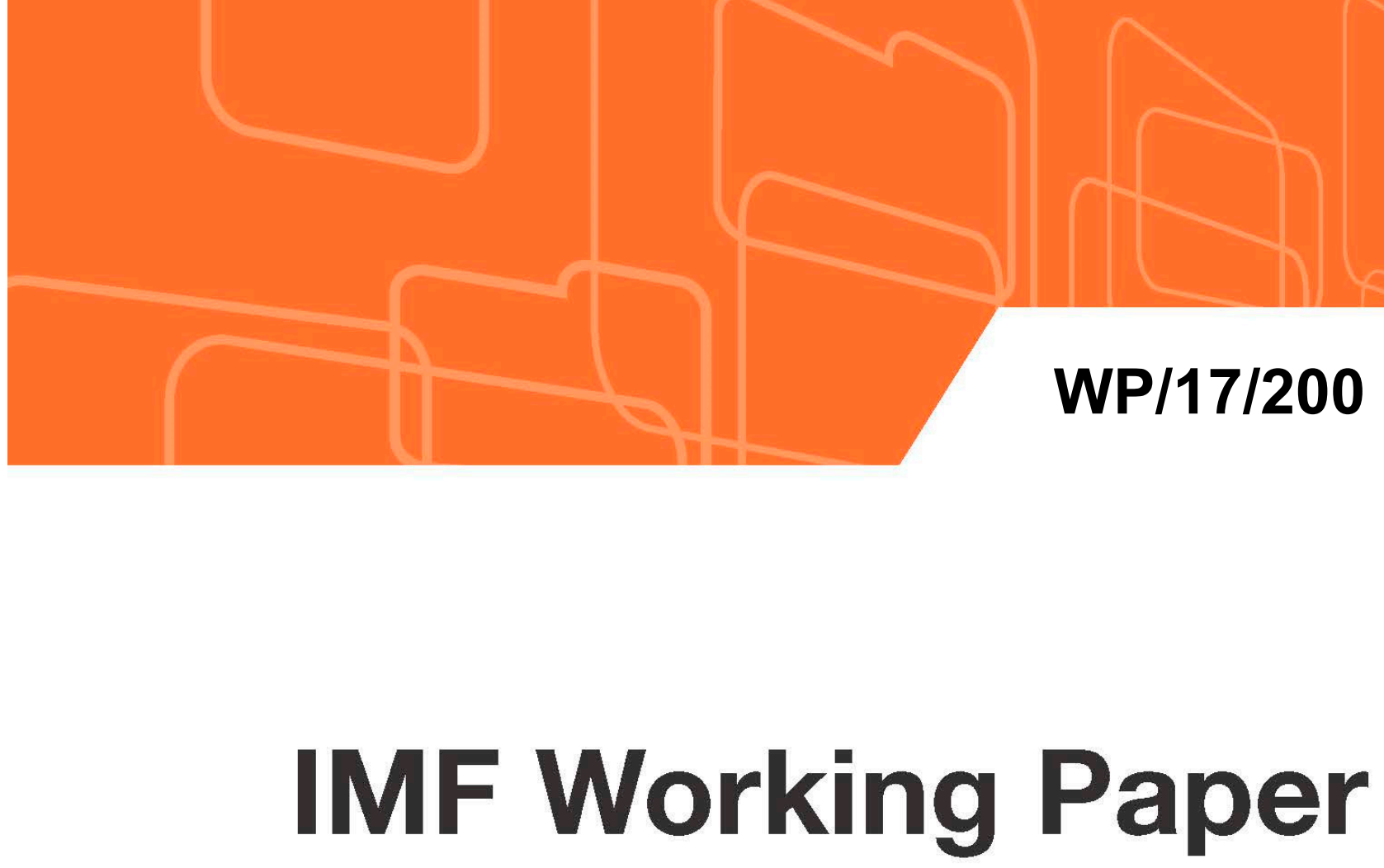

\section{The Effect of Leverage on Asset Sales Between Financial Institutions}

by Sonali Das

IMF Working Papers describe research in progress by the author(s) and are published to elicit comments and to encourage debate. The views expressed in IMF Working Papers are those of the author(s) and do not necessarily represent the views of the IMF, its Executive Board, or IMF management.

$$
\text { I N T E R N A T | O N A L M O N E T A R Y F U N D }
$$




\title{
IMF Working Paper
}

Asia and Pacific Department

\section{The Effect of Leverage on Asset Sales Between Financial Institutions ${ }^{1}$ Prepared by Sonali Das}

\author{
Authorized for distribution by Paul Cashin
}

August 2017

\section{IMF Working Papers describe research in progress by the author(s) and are published to elicit comments and to encourage debate. The views expressed in IMF Working Papers are those of the author(s) and do not necessarily represent the views of the IMF, its Executive Board, or IMF management.}

\begin{abstract}
This paper analyzes how the leverage of financial institutions affects their demand for assets and the resulting value of transactions between financial institutions. The results show a positive relationship between buyer capital and the likelihood of buying assets, and between buyer capital and the value of the deal. That is, those institutions that are the least constrained in their ability to raise funding are those that demand assets and pay more for them. This result does not hold, however, for deposit-taking institutions that had access to several government programs designed to improve their liquidity position during the crisis of 2008 .
\end{abstract}

JEL Classification Numbers: E32, G01, G21, G28

Keywords: Asset sales; financial intermediaries; balance sheets; leverage

Author's E-Mail Address: sdas2@imf.org

\footnotetext{
${ }^{1}$ An earlier version of this paper was prepared as a chapter of the author's Ph.D. dissertation at Cornell University. I would like to thank Assaf Razin, Eswar Prasad, and Matthew Freedman for helpful comments, as well as Dale Gray and seminar participants at a Canadian Economics Association conference.
} 


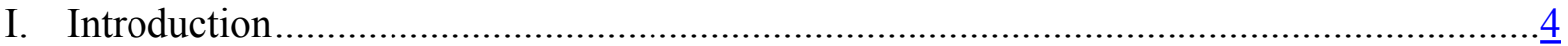

II. Access to Funding Within the Financial Sector.......................................................... 6

III. Modeling the Determinants of Asset Transaction Values ........................................... $\underline{6}$

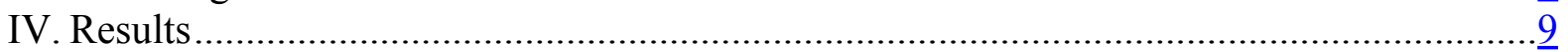

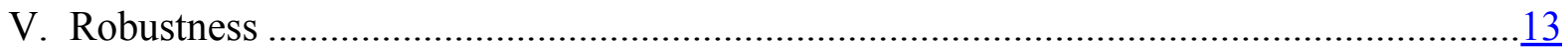

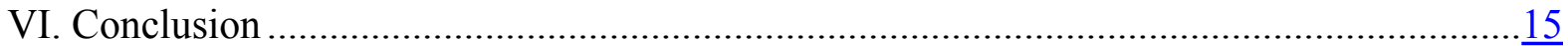

Tables

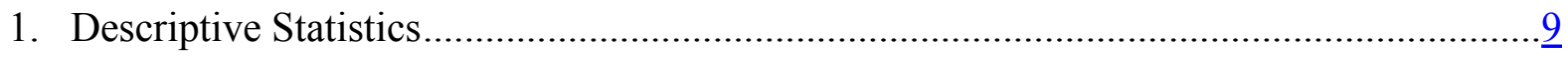

2. Determinants of Deal Probability and Deal Value ................................................ 10

3. Determinants of Deal Probability and Deal Value-Deposit Taking Institutions Versus

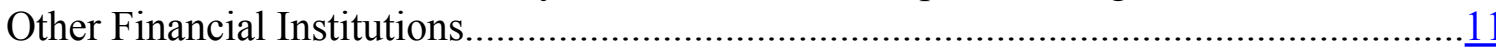

4. Determinants of Deal Probability and Deal Value - Sectoral Decomposition.................. 12

5. Determinants of Deal Value - Controlling for Type of Asset ....................................13

6. Determinants of Deal Value - U.S. Sales to Buyers in All Countries .............................14

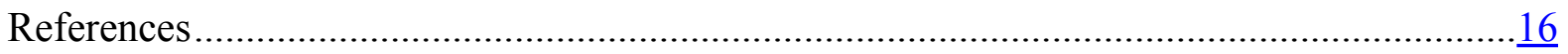




\section{INTRODUCTION}

A large restructuring of financial sector balance sheets began with the onset of the global financial crisis in 2007. The pro-cyclicality of leverage among investment banks prior to the crisis was documented (Adrian and Shin 2010) and discussions of how deleveraging can play a role in deepening crises became prominent. Shleifer and Vishny (1992) first formalized the idea of the 'fire-sale', pointing out that asset liquidation often happens when the best users are (also) credit constrained, leading to a lower liquidation value. ${ }^{2} \mathrm{He}$, Khang, and Krishnamurthy (2010) took a big picture approach to understanding financial balance sheets and showed that securitized assets shifted across financial institutions during the crisis, with the hedge funds sector reducing asset holdings while the commercial banking sector increased asset holdings and increased its leverage dramatically.

This paper provides new evidence on asset transactions between financial institutions. I first examine how the capital position of potential buyers of assets affects both their decision to purchase and the value of transactions themselves. There are two main features to theoretical studies that model fire-sales as an amplifying mechanism of liquidity crises (e.g. Brunnermeier and Pederson (2009), Krishnamurthy (2010), and Fostel and Geanakoplos (2008)): First, the amount of funding available to financial intermediaries is a function of their equity capital, up to a maximum amount. Second, the demand for assets is a function of the total funds available to intermediaries. These models focus on the constraints of the sellers and sales are assumed to be absorbed by agents who have lower valuations of the assets. The 'cash-in-the-market' pricing models of Allen and Gale $(1998,2005)$ explicitly model the buyers, however, and show that an asset's sale price will be determined by the limited amount of cash, or liquidity, held by the surviving financial intermediaries, since they are the marginal buyers. I find that the capital to assets ratio of financial institutions is positively related to both their decision to purchase assets and to the value of the transaction. In Acharya and Viswanathan's (2010) model of the financial sector, constrained firms delever after an asset quality shock by selling assets to lower leverage firms and asset-market liquidity depends on the system-wide distribution of leverage.

\footnotetext{
${ }^{2}$ See Shleifer and Vishny 2011 for a review of the literature on fire-sales of assets and their role in deepening financial instability.
} 
Recent theory has moved toward modeling how the amplification mechanism increases systemic risk. Duarte and Eisenbach (2014) construct a new systemic risk measure that quantifies vulnerability to fire-sale spillovers, and Greenwood et al. (2015) model how fire-sale spillovers add up across banks and measure a particular bank's contribution to financial sector fragility. Caballero and Simsek (2013) show how the interaction of uncertainty about cross-exposures in a financial network and fire-sales can generate instability through a complexity externality.

Second, I analyze whether there are sectoral ${ }^{3}$ differences in how buyer capital affects the demand for assets and the deal value. Based on their business models and government policies implemented during the crisis, different types of financial institutions had varying degrees of access to funding in the years after the crisis. The results of He, Khang, and Krishnamurthy (2010) suggest that certain groups of financial institutions can step in to ease liquidity problems during financial crises, but also that government liquidity policies implemented to encourage commercial banks to lend to the real sector may have had unintended effects. While their paper focuses on shifts in securitized assets at the financial sub-sector level, I analyze assets sales/purchases of real assets, such as property, at the institution level. By disaggregating to the institution level, I am able to shed light on the extent to which credit constraints affect asset demand and price across institutions that are similarly affected by policy.

I focus on the potential buyers of assets, as opposed to the sellers, for two reasons. First, distressed financial institutions sell assets for reasons that are fairly well understood. When in need of liquidity, they have three options: raise equity capital, raise debt, or sell assets for cash. Raising equity capital is thought to be costly due to debt overhang (Myers 1977) or adverse selection problems facing the potential equity investors (Myers and Majluf 1984) even in good times, so it is likely to be especially difficult or costly in times of financial distress. Second, the information on sellers of assets in the database is less detailed than that on the buyers, preventing a detailed analysis of the sellers' balance-sheets.

\footnotetext{
${ }^{3}$ By 'sectoral' I mean sub-sectors within the financial sector. These are: deposit-taking institutions (commercial and savings banks), investment banks, broker-dealers, hedge-funds, and real estate and insurance companies.
} 


\section{ACCess to Funding Within the Financial Sector}

Funding composition differs across types of financial institutions. The first distinction, in all periods and not just during crises, is that commercial and savings banks raise (partially) insured deposits, which are considered to be a relatively stable and cheap form of borrowing. ${ }^{4}$ Additionally, the coverage limit - the amount per depositor that is insured by the FDIC - was increased from $\$ 100,000$ to $\$ 250,000$ in 2008 . A second policy affecting commercial banks was the Temporary Liquidity Guarantee Program (TLGP), in place from October of 2008 to December of 2010. It allowed deposit-taking institutions to issue senior unsecured debt with a maximum three-year term, with the FDIC insuring default on these bonds for a fee of 25 to 50 basis points. Finally, the Fed cut the discount rate for commercial banks several times beginning in August 2007.

The Fed also allowed investment banks to begin borrowing directly from the discount window in March of 2008, using a broad range of debt securities as collateral. Finally, hedge funds and broker-dealers did not have access to government support and traditionally raise debt mostly in the form of repo financing. These differences in funding sources suggest that deposit-taking institutions had greater access to, or a lower cost of, funding, followed by investment banks, and then hedge-funds and broker-dealers.

\section{Modeling the Determinants of Asset Transaction Values}

The main dataset used in the analysis is the Thomson Reuters SDC Platinum M\&A database, which contains data on mergers and acquisitions of firms and on asset sales/purchases. The assets traded are real estate portfolios, loan portfolios, bank branches or units of financial institutions, and other assets such as equity investment portfolios, assetbacked securities, and information technology systems. ${ }^{5}$ I analyze deals between financial

\footnotetext{
${ }^{4}$ Runs on banks by depositors have been relatively rare in the United States since the creation of the Federal Deposit Insurance Corporation (FDIC) in 1934. Prior to the crisis of 2008, some academic economists declared depositor bank runs to be dead after the implementation of deposit insurance, while others pointed to the runs that took place in emerging market economies in which there was deposit insurance in place. The subprime crisis saw a resurgence of bank runs - first with Northern Rock in the UK and then BearStearns and IndyMac in the United States, in September 2007, March 2008, and July of 2008.

${ }^{5}$ The type of asset is not a variable given by data providers, so these were coded from a text description of the deal. The description was searched for strings such as: "home loan portfolio"; "real estate portfolio", "acquired" and "bank" and "branches"; "asset backed securities", etc. covering all the possible types.
} 
institutions located in the United States between 2005 and 2011, where the buyer is a publicly-traded company. ${ }^{6}$

To estimate a model that controls for sample selection bias arising from the possibility that a firm's characteristics affects its decision to buy assets, I start with the universe of publicly-traded financial firms in United States that are contained in the Worldscope/Datastream database. Financial firms are those with a Standard Industrial Classification code beginning with the digit 6 (division $\mathrm{H}$ ). The resulting sample is of 1116 potential buyers. This sample of potential buyers is then merged to the publicly-traded buyers in the deals database. The resulting sample is of 402 deals, representing 402 sellers and 183 unique buyers.

The main hypothesis being tested in this paper is that there is a positive relationship between the capital to assets ratio of the buyer and the value of the asset sale. ${ }^{7}$ There are two reasons to expect this. First, an institution's cash is counted in its capital ratio, so firms with higher capital may simply have more cash on hand with which to purchase assets and may have a higher willingness to pay for assets. Second, since capital ratios are often seen as a measure of health for financial institutions, those with more capital should be able to borrow on better terms (as in the leverage constraint theories of Brunnemeier and Pederson (2009) and Fostel and Geanokoplos (2008)). A second hypothesis concerns the intensity of the relationship between firm capital and deal value. As leverage constraints are more important for non-deposit taking institutions, we expect the positive relationship between buyer capital and deal value to be greater for non-deposit taking institutions.

To test these hypotheses, I use a Heckman (1979) selection model to estimate the effect of buyer capital on the value of an asset sale. Under the assumption that any unobservable characteristics that affect a financial firm's decision to buy assets are uncorrelated with unobservable characteristics that affect the value of the deal itself, ordinary least squares would produce unbiased estimates of the relationship between buyer capital and the value of an asset sale. This is too strong an assumption to make, however, as one can

\footnotetext{
${ }^{6}$ Approximately $85 \%$ of the assets sold by U.S. institutions to other financial institutions in this time period are to other U.S. institutions. Another 6\% are sold to Australian and Canadian firms, and the remaining deals are made with the following 13 countries: Belgium, France, Germany, Ireland, Israel, Japan, Mexico, Netherlands, South Korea, Spain, Switzerland, United Kingdom, and United Arab Emirates.

${ }^{7}$ By which I mean the price at which the asset is sold. I use the term 'deal value' instead of 'price' simply to make clear that the units of the assets being sold are not standardized.
} 
imagine the preferences of a manager inclined to expand during crisis times to affect his approach to negotiating on price. I present the results of the first stage selection equation, since the effect of a buyer's characteristics on its propensity to purchase an asset is interesting in itself.

Let $i=$ seller, $j=$ buyer, $t=$ year, and $E_{j t}=1$ if institution $j$ buys an asset in year $t$. The first stage selection equation is a Probit estimation of the probability that a buyer purchases an asset in a given year of the sample.

$$
\begin{aligned}
\operatorname{Pr}\left\{E_{j t}=1\right\}= & F\left\{\delta_{1}\left(\frac{\text { capital }}{\text { assets }}\right)_{j t}+\delta_{2} \log \left(\text { assets }_{j t}+\delta_{3} \text { assetgrowt }_{j t}\right.\right. \\
& \left.+\delta_{4} \log (\text { markettobook })_{j t}+v_{t}\right\}
\end{aligned}
$$

where the buyer's capital to assets ratio and size, given by the log of assets, are the main variables of interest in both the selection equation and main equation. Two other buyer characteristics, assetgrowth and markettobook, are included in the selection equation. Asset growth is the buyer's percentage increase in total assets over the previous year, to capture whether the firm has been expanding, and market-to-book is the market value of a firm's assets divided by the book value of its assets, a proxy for its potential to grow. Year dummies are included to control for macroeconomic shocks that affect all financial institutions alike. The expected signs of the coefficients are $\delta_{1}>0$ and $\delta_{2}>0, \delta_{3}>0, \delta_{4}>0$. That is, firms with more capital, larger firms, firms that have been expanding, and firms with a higher growth potential, are expected to be more likely to purchase assets.

The estimated coefficients from equation (1.1) are used to calculate the inverse Mills ratio, $\phi(\delta) / \Phi(\delta)$, which is then included in the main equation to correct for potential sample selection bias. The equation estimating the determinants of the value of asset sales is:

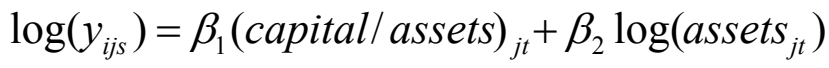

$$
\begin{aligned}
& +\theta_{21} X_{i j}+\theta_{22} \text { MarketR }_{s}+\gamma(\phi(\delta) / \Phi(\delta))_{j t}+u_{i j t}
\end{aligned}
$$

The dependent variable $\log \left(y_{i j s}\right)$ is the log of the value of a transaction between seller $i$ and buyer $j$ that takes place on day $s$ of year $t$, in millions of US dollars. The selection equation (1.1) is estimated using a buyer-year panel, while equation (1.2) is estimated on a pooled sample of deals with selection bias correction at the buyer-year level. The main explanatory 
variable of interest is the capital ratio, and the hypothesis is that $\beta_{1}>0$. The control variables included in $X_{i j}$ are indicator variables that denote whether the seller and buyer are in the same U.S. city, the same U.S. state, and the same subsector. Market $R_{S}$ is the stock market return over the month prior to the day the deal is announced, included to control for macroeconomic shocks.

Table 1 provides descriptive statistics corresponding to both the full sample of equation (1.1) and the deal (censored) observations.

Table 1. Descriptive Statistics

\begin{tabular}{|c|c|c|c|c|}
\hline & \multicolumn{2}{|c|}{ Uncensored (5823 obs) } & \multicolumn{2}{|c|}{ Censored: deal (402 obs) } \\
\hline & Mean & Std Dev & Mean & Std Dev \\
\hline Deal value, millions of US dollars & & & 351 & 1551 \\
\hline Buyer capital/assets & 31.3 & 26.5 & 71.0 & 31.1 \\
\hline Buyer assets, millions of US dollars & 20,600 & 145,000 & 67,700 & 295,000 \\
\hline Asset growth (\%), previous year & 10.6 & 22.6 & 17.5 & 27.1 \\
\hline Buyer market assets to book assets & 0.56 & 1.52 & 1.08 & 0.73 \\
\hline US stock market return, previous month & & & 0.54 & 4.61 \\
\hline Same city & & & 0.04 & 0.20 \\
\hline Same state & & & 0.28 & 0.45 \\
\hline Same sub-sector & & & 0.27 & 0.02 \\
\hline
\end{tabular}

Source: Author's calculations.

\section{Results}

I find evidence in support of the hypothesis that the value of a deal is increasing in the buyer's capital ratio. Table 2 shows the benchmark estimation results of the Heckman selection model. The positive and statistically significant coefficient lambda in column (2) indicates that unobservables in equations (1.1) and (1.2) are positively correlated, implying that there is indeed a sample selection effect and OLS is not an appropriate method to estimate equation (1.2). The estimated coefficients in column (1) show that the capital ratio, size, and asset growth of the buyer are positively related to its propensity to buy assets. The marginal effects are as follows: a 1 percentage point increase in the capital ratio (from the mean) increases the probability of a deal by 0.8 percent, a 1 percent increase in size increases the probability of a deal by 0.05 percent, and a 1 percentage point increase in asset growth increases the probability of a deal by 0.06 percent. The coefficient estimate of 0.032 on the capital ratio in column (2) indicates that a 1 percentage point increase in the capital ratio is 
associated with a 3.2 percent increase in deal value. On average, a 1 percent increase in the size (assets) of the buyer is associated with a 0.7 percent increase in the deal value. Whether the seller and buyer are located in the same U.S. city or state seem not to affect the value of the deal, but deals between firms in the same financial sector have a higher value, with the coefficient of 0.872 indicating they are priced higher by US\$ 2.4 million on average.

Table 2. Determinants of Deal Probability and Deal Value

Heckman selection model

\begin{tabular}{lcc}
\hline & $\begin{array}{c}(1) \\
\text { probability(deal })\end{array}$ & $\begin{array}{c}(2) \\
\log (\text { deal value })\end{array}$ \\
\hline Buyer capital/assets & $0.026^{* * *}$ & $0.032^{* * *}$ \\
& $(0.002)$ & $(0.008)$ \\
Buyer log(assets) & $0.178^{* * *}$ & $0.695^{* * *}$ \\
& $(0.014)$ & $(0.062)$ \\
Same city & & 0.157 \\
& & $(0.351)$ \\
Same state & & 0.180 \\
& & $(0.152)$ \\
Same sub-sector & & $0.872^{* * *}$ \\
& & $(0.199)$ \\
US stock market return & & 0.007 \\
& & $(0.014)$ \\
lambda & & $0.778^{* *}$ \\
Buyer asset growth & & $(0.337)$ \\
Buyer log(market to book) & -0.032 & \\
Observations & $(0.057)$ & \\
\hline
\end{tabular}

This table presents the results of estimating the Heckman selection model.

Column (1) shows the selection equation. The explanatory variables are the buyer's total capital to assets ratio, the buyer's size given by the log of total assets, the US stock market return over the month prior to the day the deal is announced, the buyer's growth in assets in the year prior to the deal, and the log of the buyer's market value of assets to book value of assets.

Column (2) shows the deal value equation. The dependent variable is the log of the value of the transaction, in millions of US dollars. The explanatory variables are the buyer's total capital to assets ratio, the buyer's size, indicator variables for whether the seller and buyer are based in the same city, state, whether they belong to the same sub-sector, the selection correction terms, and year dummies (not shown).

Standard errors are in parentheses below the coefficient estimates, *** indicates significance at the 1 percent level; $* *$ indicates significance at the $5 \%$ level; * indicates significance at the $10 \%$ level. 
Next, I group the buyers into deposit-taking institutions and 'non-deposit-taking' institutions, and include interaction terms for the latter in the estimation. The results (Table 3) show that it is the non-deposit-taking institutions that account for the positive relationship between buyer capital and both the likelihood of buying assets and the deal value. This is consistent with the hypothesis that the capital position of deposit-taking institutions should not affect their asset purchases as much as other institutions, as the deposit-taking ones had better access to or cheaper funding during the crisis. Table 3. Determinants of Deal Probability and Deal Value-Deposit-Taking Institutions
Versus Other Financial Institutions

Heckman selection model

\begin{tabular}{lcc}
\hline & $(1)$ & $(2)$ \\
& probability(deal) & $\log ($ deal value $)$ \\
\hline Buyer capital/assets & $-0.014^{*}$ & -0.005 \\
& $(0.008)$ & $(0.014)$ \\
Buyer capital/assets * non-deposit taking & $0.042^{* * *}$ & $0.033^{* * *}$ \\
Buyer log(assets) & $(0.009)$ & $(0.011)$ \\
& $0.198^{* * *}$ & $0.718^{* * *}$ \\
Buyer log(assets) * non-deposit taking & $(0.028)$ & $(0.062)$ \\
Same city & 0.004 & -0.001 \\
& $(0.004)$ & $(0.003)$ \\
Same state & & 0.153 \\
& & $(0.347)$ \\
Same sub-sector & & 0.205 \\
US stock market return & & $(0.151)$ \\
lambda & & $0.884^{* * *}$ \\
Buyer asset growth & & $(0.197)$ \\
Buyer log(market to book) & & 0.006 \\
Observations & & $(0.014)$ \\
\end{tabular}

This table presents the results of estimating the Heckman selection model, including an interaction term for financial institutions that do not take deposits (indicated by '* nondeposit taking'). The other explanatory variables are as in Table 2.

Standard errors are in parentheses below the coefficient estimates, $* * *$ indicates significance at the 1 percent level; ** indicates significance at the $5 \%$ level; * indicates significance at the $10 \%$ level. 
The next specification digs further into the differences between financial sub-sectors. Table 4 shows the estimation results including interaction effects for each group of non-deposittaking institutions: investment banks and other credit institutions, hedge funds and brokerdealers, and insurance and real estate. The results show no relationship between capital, the likelihood of making a purchase, and the deal value for deposit-taking institutions. There is a significant and positive relationship between capital and the deal probability for each other type of potential buyer, however.

\section{Table 4. Determinants of Deal Probability and Deal Value-Sectoral Decomposition}

Heckman selection model

\begin{tabular}{|c|c|c|}
\hline & $\begin{array}{c}(1) \\
\text { probability(deal) }\end{array}$ & $\begin{array}{c}(2) \\
\log (\text { deal value }) \\
\end{array}$ \\
\hline Buyer capital/assets & $\begin{array}{l}-0.009 \\
(0.007)\end{array}$ & $\begin{array}{c}0.001 \\
(0.018)\end{array}$ \\
\hline Buyer capital/assets * Inv bank \& other credit & $\begin{array}{c}0.016^{* *} \\
(0.007)\end{array}$ & $\begin{array}{l}-0.004 \\
(0.019)\end{array}$ \\
\hline Buyer capital/assets * Hedge fund \& broker-dealers & $\begin{array}{c}0.040 * * * \\
(0.007)\end{array}$ & $\begin{array}{c}0.008 \\
(0.021)\end{array}$ \\
\hline Buyer capital/assets * Insurance \& real estate & $\begin{array}{c}0.023 * * * \\
(0.007)\end{array}$ & $\begin{array}{c}0.015 \\
(0.019)\end{array}$ \\
\hline Buyer $\log$ (assets) & $\begin{array}{c}0.167 * * * \\
(0.022)\end{array}$ & $\begin{array}{c}0.516 * * * \\
(0.067)\end{array}$ \\
\hline Buyer $\log ($ assets $) *$ Inv bank \& other credit & $\begin{array}{c}0.019 \\
(0.024)\end{array}$ & $\begin{array}{c}0.138 * * * \\
(0.053)\end{array}$ \\
\hline Buyer $\log ($ assets $) *$ Hedge fund $\&$ broker-dealers & $\begin{array}{l}0.005 \\
(0.032)\end{array}$ & $\begin{array}{c}0.221 * * * \\
(0.062)\end{array}$ \\
\hline Buyer $\log ($ assets $) *$ Insurance $\&$ real estate & $\begin{array}{c}-0.066^{* * *} \\
(0.022)\end{array}$ & $\begin{array}{c}0.093 \\
(0.069)\end{array}$ \\
\hline Same city & & $\begin{array}{c}0.213 \\
(0.347)\end{array}$ \\
\hline Same state & & $\begin{array}{c}0.160 \\
(0.152)\end{array}$ \\
\hline Same sub-sector & & $\begin{array}{c}0.743 * * \\
(0.302)\end{array}$ \\
\hline US stock market return & & $\begin{array}{c}0.007 \\
(0.014)\end{array}$ \\
\hline lambda & & $\begin{array}{c}0.329 \\
(0.356)\end{array}$ \\
\hline Buyer asset growth & $\begin{array}{c}0.001 \\
(0.001)\end{array}$ & \\
\hline Buyer $\log ($ market to book $)$ & $\begin{array}{c}-0.163 * * * \\
(0.063)\end{array}$ & \\
\hline Observations & 5823 & 402 \\
\hline
\end{tabular}

Notes: This table presents the results of estimating the Heckman selection model, including interaction terms for the financial sub-sector of the buyer. Indicator variables for the sub-sector of both the seller and buyer are included as well (not shown). The category left out is deposit-taking banks. The other explanatory variables are as in Table 2 . Standard errors are in parentheses below the coefficient estimates, *** indicates significance at the 1 percent level; ** indicates significance at the $5 \%$ level; $*$ indicates significance at the $10 \%$ level. 


\section{ROBUSTNESS}

I perform two robustness exercises in this section. First, I estimate the selection model using the subset of deals for which the type of assets (e.g. building versus loan portfolio) was coded and control for the asset type, to ensure the results are not driven by a relationship between buyer capital and the class of assets purchased. In these 252 deals, 88 percent are properties, 7 percent are loan portfolios, and 5 percent are units or branches of banks. The results are shown in Table 5. The coefficient on the buyer's capital ratio and the other explanatory variables are very close to the benchmark estimation. The dummy variables for asset type indicate that loan portfolios sell for US\$ 2.24 million more than properties, on average.

Table 5. Determinants of Deal Value_Controlling for Type of Asset

\begin{tabular}{lcc} 
Heckman selection model & & \\
& $(1)$ & $(2)$ \\
& probability(deal) & $\log ($ deal value $)$ \\
\hline Buyer capital/assets & $0.036^{* * *}$ & $0.066^{* * *}$ \\
Buyer log(assets) & $(0.002)$ & $(0.015)$ \\
& $0.199^{* * *}$ & $0.767^{* * *}$ \\
Same city & $(0.019)$ & $(0.091)$ \\
& & -0.141 \\
Same state & & $(0.395)$ \\
& & $0.456^{* * *}$ \\
Same sub-sector & & $(0.170)$ \\
& & $0.993^{* * *}$ \\
US stock market return & & $(0.346)$ \\
& & -0.005 \\
Asset type: loan portfolio & & $(0.016)$ \\
& & $0.810^{*}$ \\
Asset type: bank branch/unit & & $(0.442)$ \\
& & 0.572 \\
lambda & & $(0.642)$ \\
Buyer asset growth & & $\left(0.193^{* * *}\right.$ \\
Buyer log(market to book) & $-0.127^{*}$ & \\
Observations & $(0.074)$ & \\
& 5673 & 252 \\
\hline
\end{tabular}

Notes: This table shows the results of estimating the two-stage model on a subsample of data for which the type of asset - be it real estate property, a loan portfolio, or a unit or branch of a bank - was coded. The category 'property assets' is left out, while indicators for 'loan portfolio' and 'bank branch/unit' are included. The variables are described in table 2. Standard errors are in parentheses below the coefficient estimates, *** indicates significance at the 1 percent level; ** indicates significance at the 5\% level; * indicates significance at the $10 \%$ level. 
Finally, Table 6 shows the results of estimating equation (1.2) on the full sample of transactions involving US sellers - those bought by US firms as well as the other 15 countries listed in the data section. ${ }^{8}$ The estimated coefficients are close to the estimates from the benchmark estimation shown in Table 2. The increase in value when a deal occurs between two firms in the same sector is now smaller, however, by about 1 million US dollars. In column (2), I include an interaction term for buyers that are from countries that were in financial crisis starting in 2007 or 2008, according to the classification by Laeven and Valencia (2008). This includes the United States. There does not appear to be a different effect of capital on deal value when the buyer is from a country in crisis. The positive effect of buyer size on deal value is larger when the buyer is from a crisis country, however.

Table 6. Determinants of Deal Value-U.S. Sales to Buyers in All Countries

\begin{tabular}{lcc} 
OLS & & \\
\hline & $(1)$ & $(2)$ \\
\hline Buyer country in crisis & $-1.956^{*}$ \\
& & $(1.016)$ \\
Buyer capital/assets & $0.015^{* * *}$ & $0.015^{* * *}$ \\
& $(0.003)$ & $(0.003)$ \\
Buyer capital/assets * buyer country crisis & & -0.007 \\
& & $(0.006)$ \\
Buyer log(assets) & $0.563^{* * *}$ & $0.528^{* * *}$ \\
& $(0.039)$ & $(0.042)$ \\
Buyer log(assets) * buyer country crisis & & $0.328^{* * *}$ \\
& & $(0.083)$ \\
Same city & 0.062 & 0.128 \\
& $(0.291)$ & $(0.284)$ \\
Same sub-sector & $0.447^{* *}$ & $0.443^{* *}$ \\
& $(0.194)$ & $(0.190)$ \\
(Buyer - US) stock market return & 0.028 & 0.037 \\
& $(0.072)$ & $(0.073)$ \\
Observations & 591 & 591 \\
Adj Rsquared & 0.36 & 0.38 \\
\hline
\end{tabular}

Notes: This table presents the estimation of the deal value equation using OLS, including institutions in all countries that purchased an asset from the United States. 'buyer country crisis' is an indicator variable for whether the buyer's country is in a financial crisis, starting in 2007/2008, according to the Laeven and Valencia (2008) classification. (Buyer - U.S.) stock return is the difference the in the stock market return of the buying institutions' country and the U.S. return. The other variables are as in Table 2. Standard errors are in parentheses below the coefficient estimates, ${ }^{* * *}$ indicates significance at the 1 percent level; $* *$ indicates significance at the $5 \%$ level; $*$ indicated significance at the $10 \%$ level.

\footnotetext{
${ }^{8}$ I do not estimate a selection model here because (1) the data for countries other than the United States are less conducive to identifying the universe of potential buyers and (2), even having done so, the number of 'zeros' (non-purchases) in the selection equation would be problematic for the estimation. Only 15 percent of sales from U.S. firms had foreign buyers. A potentially fruitful future project would be to study deals between a broader set of countries.
} 


\section{Conclusion}

I study the sale and purchase of real assets between financial institutions in the United States and find that greater capital, or lower leverage, increases the probability that a potential buyer will purchase an asset and also increases the value of the deal that takes place. These results do not hold for deposit-taking institutions, however, who had greater access to or cheaper funding during the financial crisis. The results are consistent with theories that model demand for assets as a function of funding availability, and show that credit-constraints of financial intermediaries can interact to reduce asset prices and deepen liquidity crises. By showing that leverage affects the purchases of real assets for most financial firms, the findings reinforce the results of He, Khang, and Krishnamurthy (2010) who focus on securitized assets. They also strengthen the implication that government liquidity policies implemented to encourage commercial banks to lend to the real sector may have had the unintended effect of facilitating an accumulation of non-loan assets. 


\section{REFERENCES}

Acharya, Viral V., and S. Viswanathan, 2011, "Leverage, Moral Hazard, and Liquidity," Journal of Finance, Vol. 66 (1), pp. 99-138.

Acharya, Viral V., Gujral, Irvind and Shin, Hyun Song, 2009, "Dividends and Bank Capital in the Financial Crisis of 2007-2009" (March 18, 2009). Available at SSRN: https://ssrn.com/abstract=1362299

Adrian, Tobias, and Hyun Song Shin, 2010, "Liquidity and Leverage," Journal of Financial Intermediation, Vol. 19 (3), pp. 418-37.

Allen, Franklin and Douglas Gale, 1994, "Limited Market Participation and Volatility of Asset Prices," American Economic Review, Vol. 84 (4), pp. 933-955.

Allen, Franklin and Douglas Gale, 1998, "Optimal Financial Crises," Journal of Finance, Vol. 53, No. 4, pp. 1245-1284.

Allen, Franklin and Douglas Gale, 2005, "From Cash-in-the-Market Pricing to Financial Fragility," Journal of the European Economic Association, Vol. 3 (2-3), pp. 535-546.

Brunnermeier, Markus, and Lesse Pedersen, 2009, "Market Liquidity and Funding Liquidity," Review of Financial Studies, 22(6), pp. 2201-38.

Caballero, Ricardo J. and Alp Simsek, 2013, "Fire Sales in a Model of Complexity," The Journal of Finance, Vol. 68, pp 2549-2587.

Duarte, Fernando and Thomas M. Eisenbach, 2015, "Fire-Sale Spillovers and Systemic Risk,” Federal Reserve Bank of New York Staff Reports, no. 645, February 2015.

He, Zhiguo; In Gu Khang and Arvind Krishnamurthy, 2010, "Balance Sheet Adjustment in the 2008 Crisis," IMF Economic Review, Vol. 1, pp. 118-156.

Heckman, James J.,1979, “Sample Selection Bias as a Specification Error," Econometrica, Vol. 47(1), pp. 153-61.

Fostel, Ana and John Geanakoplos, 2008, "Leverage Cycles and the Anxious Economy," American Economic Review, Vol. 98 (4), pp. 1211-1244.

Greenwood, R., A. Landier, and D. Thesmar, 2015, "Vulnerable banks," Journal of Financial Economics, Vol. 115 No. 3, pp. 471-485.

Krishnamurthy, Arvind, 2010, "How Debt Markets Have Malfunctioned in the Crisis," Journal of Economic Perspectives, Vol. 24, No. 1, Winter 2010, pp. 3-28. 
Kyle, A., and W. Xiong, 2001, "Contagion as a Wealth Effect," Journal of Finance, Vol. 56, pp. 1401-1440.

Myers, S., 1977, "Determinants of Corporate Borrowing," Journal of Financial Economics, Vol. 5, pp. 147-75.

Myers, S., Majluf, N., 1984, "Corporate financing and investment decisions when firms have information that investors do not have," Journal of Financial Economics, Vol. 13, pp. $187-221$.

Shleifer, Andrei, and Robert W. Vishny, 1992, "Liquidation Values and Debt Capacity: A Market Equilibrium Approach,” Journal of Finance, Vol. 47 (4), pp. 1343-66.

Shleifer, Andrei, and Robert Vishny, 2011, "Fire Sales in Finance and Macroeconomics," Journal of Economic Perspectives, Vol. 25(1), pp. 29-48. 